\title{
"Determinants of Broadband Access: Is Platform Competition always the Key Variable to Success?"
}

Xavier Fageda, Rafael Rubio and Montserrat Termes 


\section{$\overbrace{\circledast}|| R|E| A \mid$}

Institut de Recerca en Economia Aplicada Regional i Pública

Research Institute of Applied Economics

\section{Universitat de Barcelona}

Av. Diagonal, 690 08034 Barcelona

WEBSITE: www.ub.edu/irea/•CONTACT: irea@ub.edu

The Research Institute of Applied Economics (IREA) in Barcelona was founded in 2005, as a research institute in applied economics. Three consolidated research groups make up the institute: AQR, RISK and GiM, and a large number of members are involved in the Institute. IREA focuses on four priority lines of investigation: (i) the quantitative study of regional and urban economic activity and analysis of regional and local economic policies, (ii) study of public economic activity in markets, particularly in the fields of empirical evaluation of privatization, the regulation and competition in the markets of public services using state of industrial economy, (iii) risk analysis in finance and insurance, and (iv) the development of micro and macro econometrics applied for the analysis of economic activity, particularly for quantitative evaluation of public policies.

IREA Working Papers often represent preliminary work and are circulated to encourage discussion. Citation of such a paper should account for its provisional character. For that reason, IREA Working Papers may not be reproduced or distributed without the written consent of the author. A revised version may be available directly from the author.

Any opinions expressed here are those of the author(s) and not those of IREA. Research published in this series may include views on policy, but the institute itself takes no institutional policy positions. 
Previous studies have identified the rivalry among technological platforms as one of the main driving forces of broadband services penetration. This paper draws on data from the Spanish market between 2005 and 2011 to estimate the main determinants of broadband prices. Controlling for broadband tariffs features and network variables, we examine the impact of the different modes of competition on prices. We find that inter-platform competition has no significant effects over prices, while intra-platform competition is a key driver of the prices charged in the broadband market. Our analysis suggests that the impact of different types of competition on prices is critically affected by the levels of development of the broadband market achieved by the considered country.

JEL classification: L38, L51, L96

Keywords: broadband prices, inter-platform competition, intra-platform competition.

Xavier Fageda: Department of Economic Policy \& GiM-IREA, Universitat de Barcelona (Barcelona, Spain) (xfageda@ub.edu).

Rafael Rubio: Department of Economic Policy \& GiM-IREA, Universitat de Barcelona, (Barcelona, Spain) (rrubio@ub.edu)

Montserrat Termes: Department of Economic Policy \& GiM-IREA, Universitat de Barcelona, (Barcelona, Spain) (mtermes@,ub.edu)

The views and opinions expressed herein are solely those of the author and do not necessarily reflect those of the Comisión del Mercado de las Telecomunicaciones (CMT). 


\section{Introduction}

Over the last decade, many governments have considered access to high-speed data networks otherwise known as broadband networks ${ }^{1}$ - a priority in the design of their economic growth policies. One of the most recent examples lending support to this assertion can be found in the 2009 American Recovery and Reinvestment Act, which comprised a package of measures to stimulate the U.S. economy: among the items budgeted were 7,200 million dollars assigned to the completion of broadband networks.

The expansion of broadband technology has been reported as having a major impact on the economic growth of a country. Koutroumpis (2009) found that a $1 \%$ increase in the penetration rate of broadband services in 22 OECD countries resulted in a $0.025 \%$ increase in their growth rate. Qiang and Rossotto (2009) conducted a similar exercise in a study that grouped countries according to their income level. Their results suggested that in high-income countries, each additional percentage point in broadband penetration amounted to a $0.121 \%$ increase in the GDP growth rate while for low- and middle-income countries it represented a $0.138 \%$ increase.

In the light of these findings, Katz and Suter (2009) sought to quantify the expected impact of the measures promoting broadband penetration in the 2009 American Recovery and Reinvestment Act. They estimated the effect of investments to be the direct creation of over 128,000 jobs and the formation of network externalities that would generate a further 270,000 jobs over the following four years.

\footnotetext{
${ }^{1}$ There are three main network types known as broadband platforms:

xDSL (Digital Subscriber Line) Platforms: xDSL technology is based on the conversion of the copper pair telephone line into a basic high-speed digital line that can carry broadband services as well as transmit voice. The connection speed of this technology ranges from $256 \mathrm{Kbps}$ to $40 \mathrm{Mbps}$.

Cable modem platforms or HFC (hybrid-fiber coaxial): These hybrid networks combine optical fiber and coaxial cable. Cable platforms were deployed in many countries before the emergence of the broadband internet service as initially they were built to broadcast television frequencies. Later, in the mid-90s, TV cable operators adapted their facilities so as to offer broadband internet services too. Cable platforms can achieve data transmission speeds in excess of $100 \mathrm{Mbps}$.

Optical Fiber Platforms or FTTx: Today, this technology permits the highest data transmission speed for internet access. Fiber optic platforms can offer internet data speeds higher than 1 Gbps.
} 
Thus, while there may be some discrepancies in the exact impact of the expansion of broadband networks, all studies seem to report a positive impact on economic growth. For this reason, governments continue to implement policies aimed at promoting access to broadband. However, direct government investment is not the only way to promote the technology with one of the basic tools for enhancing the penetration of broadband services being the promotion of competition among telecommunication operators. In recent years, the debate as to what constitutes the best market structure for maximizing such competition has been lively.

Two types of competition have developed in most broadband markets: first, inter-platform competition, i.e., competition between two technology platforms (typically xDSL and cable platforms) in the same area; and, second, intra-platform competition, i.e., competition between operators using the same technology platform (as we shall see below, this type of competition is limited to XDSL platforms and requires regulatory intervention).

Various studies (Distaso et al., 2006; Bouckaert et al., 2010) have analyzed the market in these terms and present evidence to indicate that inter-platform competition is the driving force behind the expansion of broadband services, while they have tended not to find a positive impact in the case of intra-platform competition.

This paper draws on data from the Spanish market between 2005 and 2011. The market was characterized by a low level of broadband diffusion among the population and the charging of higher prices than those applied in many European countries. Our aim here is to determine whether the results for the Spanish market verify previous empirical findings regarding competition (i.e., the dominance of inter-platform competition) and to identify the causes of the delayed development of broadband technology in this specific market. Although the study focuses on Spain, our findings should be valid for other countries with a similar development of broadband technology.

The empirical analysis reported here makes two main contributions to the literature. First, we examine the effects of different competition modes on broadband price levels as opposed to their impact on penetration rates, which is the usual variable studied in the literature. Second, we take into account all the prices of each telecom operator in the Spanish market, whereas previous studies have opted to use aggregated data at the national level. This approach allows us to examine the specific impact individual operators might have on market price performance. In contrast with previous studies, we find that intra-platform competition has been the main driver of price levels, while the impact of inter-platform competition has been insignificant. 
The rest of this paper is organized as follows. Section 2 provides a brief overview of the development of broadband technology, focusing on the situation of the Spanish market. Section 3 describes different forms of competition in the broadband market and reviews the literature. Section 4 presents the empirical model and discusses the results. Section 5 closes with a summary of the main results and their implications for public policy.

\section{Origin and development of broadband platforms}

The need for deploying broadband networks among a high percentage of the population results from the technological revolution initiated by the expansion of the internet in the early 1990s. At the outset, most users had a narrowband access to internet based on a dial-up modem via a standard phone line. However, the exponential growth of Internet connections explains why these narrowband networks, which were nevertheless crucial for internet development, became an obstacle as users sought to access services requiring markedly higher connection speeds. The telecommunications industry responded to these new demands - both from the residential and business segments - by developing new technology platforms (i.e., xDSL, cable modem and FTTx), the so-called broadband networks.

Since the creation of these platforms, the number of broadband users has grown exponentially. An OECD study conducted in 2011 reported that up to a quarter of the population of its member countries accessed internet via broadband platforms, equivalent to 309 million broadband users. Moreover, in the last decade, broadband had experienced annual growth rates higher than $40 \%$. The study also reported that certain European countries -including, France, the UK and Germany - all presented very similar levels of penetration and all of them above the OECD average. By contrast, a group of other countries - including, Spain, Austria, Italy and Greece - found themselves lagging some distance behind the leading group and at levels below the OECD average.

Three main groups of operators can be identified in the Spanish broadband market: 1) the incumbent who owns the public switched telephone network deployed in the country - Telefónica de España, 2) cable operators who provided their own network access nationally or regionally, and 3) alternative xDSL operators that need to access, at least partially, the incumbent operator's network to offer their broadband services. FTTx or WiMAX access technologies have only a residual presence in Spain. 
Table 1. Development of broadband platforms in Spain

\begin{tabular}{|c|c|c|c|c|}
\hline & \multirow{2}{*}{ Coverage } & \multicolumn{2}{|c|}{ Market Share (\%) } & \multirow{2}{*}{$\begin{array}{r}\text { Variation } \\
(\%)\end{array}$} \\
\hline & & 2004 & 2011 & \\
\hline Narrowband platforms & National & $35.2 \%$ & $0.5 \%$ & $-98.5 \%$ \\
\hline Broadband platforms & National/Regional & $64.8 \%$ & $99.5 \%$ & $53.6 \%$ \\
\hline Incumbent Operator & National & $54.9 \%$ & $49.2 \%$ & $-10.5 \%$ \\
\hline xDSL alternative operators & National & $16.3 \%$ & $29.6 \%$ & $81.8 \%$ \\
\hline unbundled local loop (\%) & & $27.8 \%$ & $79.5 \%$ & $186.0 \%$ \\
\hline bitstream (\%) & & $72.2 \%$ & $20.5 \%$ & $-71.6 \%$ \\
\hline Cable operator & National & $21.2 \%$ & $14.3 \%$ & $-32.6 \%$ \\
\hline Others cable operators & Regional & $4.9 \%$ & $6.5 \%$ & $31.7 \%$ \\
\hline $\begin{array}{c}\text { Other platforms } \\
\text { WiMAX) }\end{array}$ & Regional & $0.4 \%$ & $0.5 \%$ & $12.9 \%$ \\
\hline
\end{tabular}

Table 1 shows that, since 2004, alternative xDSL operators have increased their market significantly - almost doubling their market presence, while Telefónica de España and national cable operators have suffered a significant loss of their market share. Particularly notable has been the evolution of national cable operators, whose market share has fallen by 32.6 per cent over the last seven years. Regional cable operators have fared better but their market share -6.5 per cent - remains small in national terms. Finally, Table 1 shows, as mentioned above, that virtually no internet users today access via narrowband platforms.

The international comparison of prices in the broadband market is complicated for various reasons, including: nonlinear pricing structures (that is, flat rates that include a single fixed fee for a service, regardless of usage), the great variety of commercial offers (tariffs with several connection speeds or with a monthly data allowance) and the existence of multiproduct services (i.e., bundled products combining fixed telephony, television, etc.). Yet, despite these difficulties, several organizations - including the OECD, ITU and $\mathrm{CMT}^{2}$ - have sought to undertake an international comparison of broadband prices. The CMT, for example, publishes a half-yearly study of broadband tariffs reporting the prices of bundled offers (including broadband and fixed telephony voice services) in Spain compared to average EU prices (see Figure 1). This offer is used as the reference price for broadband services since it is the most heavily demanded product in the Spanish market, accounting for 73.4 per cent of all broadband contracts.

\footnotetext{
${ }^{2}$ Comisión del Mercado de las Telecomunicaciones - Spain's regulator of the telecom sector.
} 
Figure 1. Price comparison of fixed bundled tariffs, June 2010

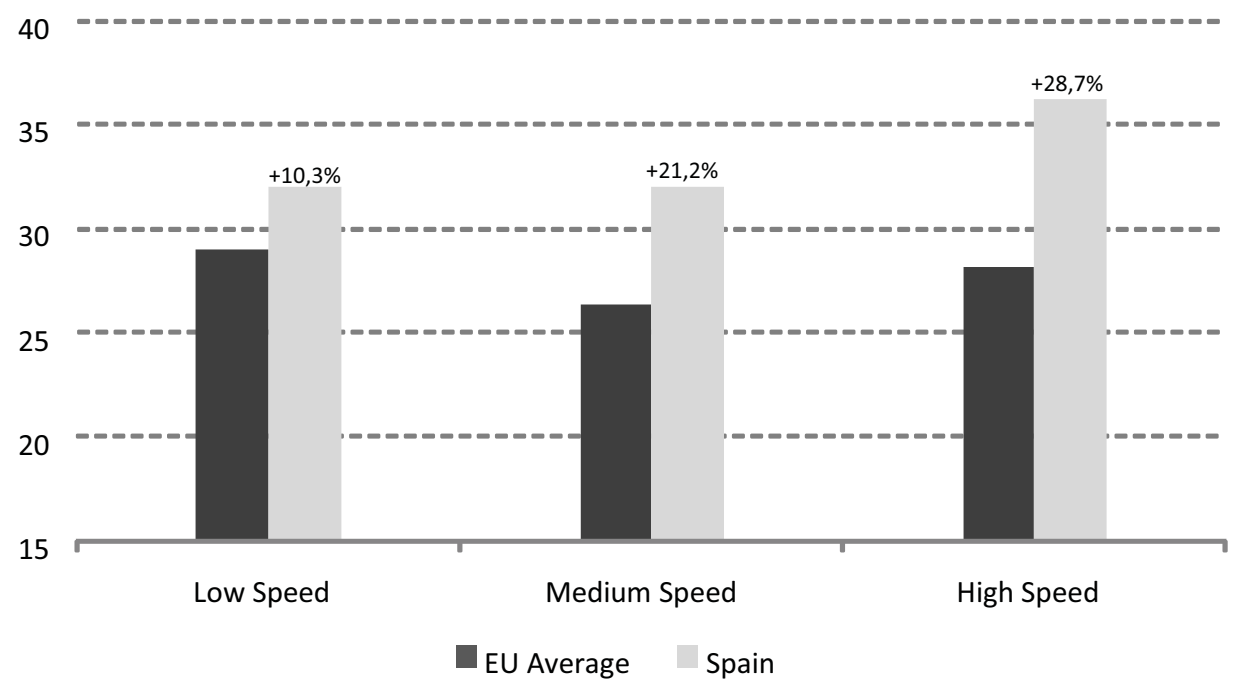

Source: Based on information supplied by CMT

The report shows that the prices of broadband services in Spain are significantly higher than those charged on average in the EU. Likewise, the reports published by international organizations ${ }^{3}$ present similar findings.

In short, Spain's broadband market charges higher prices than those of its EU counterparts, while the penetration rate remains low with respect to these countries. This situation may well be indicative of an abnormality in the level of competition, with the effect that Spain's market is some way from achieving optimum conditions of competition. For this reason, this study seeks to identify the impact of different forms of competition on the Spanish market and to quantify their influence on the expansion of broadband services.

3 See Van Dijk Management Consultants (2010) Broadband Internet Access Cost (BIAC). European Commission, Information Society and Media Directorate-General, Brussels. 


\section{Modes of competition in the broadband market}

The aim of this paper is to examine the influence of different types of competition on prices in the broadband market. In this regard, previous studies have detected two types of competition: inter-platform and intra-platform competition. The main features of each of these modalities are summarized below.

\subsection{Inter-platform competition}

Historically, in Spain - as in most other European countries - only one telecom operator (Telefónica de España) supplied the market under monopolistic conditions and was responsible for the deployment of the telecommunications network throughout the country. The public switched telephone network (PSTN) was based on twisted copper pair cabling facilities which carried voice analog signals between telephone exchanges and customers' homes. Later, with the digitization of analog signals, it became possible to offer broadband internet services via the PSTN using xDSL technology.

However, xDSL platforms are not the only telecommunications network to offer broadband services. Thus, in the early 1990s new telecom operators started to offer broadband services via alternative platforms ${ }^{4}$. The platform that has enjoyed the greatest success has been the coaxial cable network (HFC).

Today, broadband internet access in Spain is provided principally by two technology platforms: xDSL and cable. The two platforms are completely independent of each other and there is no need to establish an interconnection to provide internet access. This means that the competition between telecom operators providing different platforms (either cable or xDSL) presents different characteristics to those that typify other forms of competition.

\subsection{Intra-platform competition}

The main barrier to entry that new operators must overcome in a market such as that of broadband internet access is the high level of initial investment required to deploy their own platform. One way of reducing this risk is to allow potential operators to lease the incumbent's

\footnotetext{
${ }^{4}$ Fixed Wireless Access (WiMax), Satellite or Cable Platforms.
} 
network facilities in exchange for a rental fee fixed by the national regulatory authority (NRA). Cave et al. (2001) claim that new operators would tend to start their activity by renting the incumbent's network, since their volume of investment in their own facilities is initially very low. Later, as the new operators increase their volume of investment, their independence increases with respect to the incumbent's network. Via this process, known as the investment ladder theory, new operators are encouraged to become progressively more competitive.

Thus, on the first rungs of the investment ladder, entrants deploy only a small volume of their own facilities. Subsequently, the new entrants begin to invest in more expensive facilities, typically ones that are more difficult to replicate, until they reach the higher rungs of the ladder. Thus, it is the objective of the NRA to ensure that new operators reach these higher investment rungs since the more independent they can become of the incumbent, the more capable they are of offering high quality services at competitive prices. In order to attain this goal, NRAs regulate the prices charged to entrant operators at each step in the market access process. The prices fixed serving as incentive for operators to start making their own investments. Thus, Cave and Vogelsang (2003) recommend charging new entrants low prices to access the incumbent's network but then gradually increasing prices according to the replicability of each level.

The culmination of this process should ensure a high competitiveness of alternative operators and enable users to reap the benefits of a high level of market competition (primarily, lower prices and higher rates of domestic broadband penetration). As such, intra-platform competition is generated by operators using totally - or partially - the same technological platform (in this case the xDSL platform). Moreover, the characteristics of this competition differ from those in which different technological platforms compete - i.e., inter-platform competition.

A number of empirical studies (Wallsten, 2006; Bouckaert et al., 2010) split intra-platform competition according to the type of access gained by the alternative operator to the incumbent's platform. Thus, they distinguish between service-based competition and facilities-based competition. The former involves operators on the lower rungs of the investment ladder that provide telecommunication services via resale or bitstream access. In this case, operators are not required to invest heavily but rather rent most of the incumbent's facilities. The latter involves operators that only rent local loop access from the incumbent, with the corresponding need to invest in their own facilities.

Our objective in what follows is to identify the type of competition - inter- or intra-platform that has had the greatest impact on the development of broadband internet access in Spain. However, at the same time, we also seek to analyze the additional impact of each of these two forms of intra-platform competition. 


\subsection{Empirical studies: Inter-platform vs. intra-platform competition}

In their study of 46 US states, Aron and Burnstein (2003) found inter-platform competition to be a significant and positive variable for explaining the broadband penetration rate. Additionally, they claim that providing new entrants with unbundled local loop access might affect their incentives to invest in their own alternative platforms. Similarly, Garcia-Murillo and Gabel (2003) argue that there is no evidence to suggest that unbundled local loop access is associated with greater rates of broadband adoption.

Distaso et al's. (2006) study is more similar to ours as it seeks to determine whether it is better to promote competition between xDSL platform operators (i.e., intra-platform competition) or to stimulate the entry of new platform operators thereby promoting competition in a multiplatform environment (i.e., inter-platform competition). They found the inter-platform concentration variable to be negative and statistically significant, demonstrating that this competition mode was the main driver of the diffusion of broadband services. By contrast, the intra-platform concentration variable was positive and non-significant, suggesting that the positive effect attributable to a higher degree of intra-platform competition is offset by its negative impact on inter-platform competition.

These results are supported by Bouckaert et al. (2010) who analyzed broadband penetration rates across 20 OECD countries from December 2003 to March 2008. They failed to find results that lend empirical support to the investment ladder theory; indeed, their evidence suggests that encouraging intra-platform competition may be negative for promoting investment in telecommunication networks. By contrast, they found that higher values of inter-platform competition led to higher levels of broadband adoption. Furthermore, they suggest that servicebased intra-platform competition - i.e., alternative operators providing bitstream access - could undermine broadband diffusion.

In short, most empirical studies identify inter-platform competition as the key policy driver for promoting broadband adoption and facility investment. By contrast, intra-platform competition does not appear to have a significantly positive effect, and some studies even suggest it might have a negative impact on broadband development. The main aim of this current study is to assess whether inter-platform competition is the main dynamic force in promoting broadband adoption in the Spanish market. 


\section{Empirical analysis}

In this section, we outline the data, variables and the empirical model that we develop to analyze the impact of different types of competition on prices. Specifically, we estimate an empirical model in which the dependent variable is the price of broadband services supplied by Spanish telecom operators. The explanatory variables capture different attributes of tariffs, as well as the intensity of intra- and inter-platform competition.

The data were collected from various sources. Broadband access information is taken from the quarterly and annual reports published by CMT, the Spanish telecommunications authority. Broadband access prices are taken from the webpages of the telecom operators and from the Comparativa internacional de ofertas comerciales de banda ancha, a biannual report of broadband access prices published by CMT (2007 to 2011).

Given the threefold classification of broadband access operators (the xDSL incumbent operator and owner of the PSTN; alternative xDSL operators that access, at least partially, the incumbent operator's network; and cable operators using their own access platform), in order to represent the Spanish market structure faithfully, data have been collected from six telecom operators: the incumbent (Telefónica de España), four alternative xDSL operators (Vodafone, Jazztel, Orange and Ya.com) and, finally, one cable operator (ONO). The data used in this study range over 14 periods with each operator being observed in quarterly time intervals between December 2005 and June 2011. However, data are not available for all six operators for the entire period for various reasons - including, for example, merger and acquisition processes between the companies $^{5}$. Consequently, we work with an unbalanced panel data, containing a total of 138 observations.

\subsection{Dependent variable: prices}

Most earlier studies employ the broadband penetration rate as their dependent variable. One of the main contributions of our study, however, is to estimate the impact of different modes of competition on broadband service prices, as opposed to on the broadband penetration rate. Thus, the dependent variable here is constructed from the broadband access tariffs offered by telecom operators.

\footnotetext{
${ }^{5}$ In June 2007, for example Ya.com was absorbed by Orange for 320 million euros.
} 
Given the wide range of broadband access services available on the market (different data transfer speeds, broadband access bundled - or otherwise - with other telecommunication services, etc.) we considered it necessary to establish a selection criterion for tariffs that provides a faithful representation of the prices fixed by each operator. Thus, each broadband operator is represented by two tariffs: first, its lowest tariff (best entry) and, second, the tariff contracted by the highest number of customers. The frequency of the data is biannual.

\subsection{Competition variables}

As noted above, we are primarily concerned with measuring the impact of each mode of competition - inter-platform and intra-platform - on broadband access prices in the Spanish market. Our reason for analyzing a specific geographic market is to confirm if the variables that have been shown to affect broadband penetration rates internationally - and, at the same time, broadband access prices - maintain this effect in the Spanish case. However, unlike previous studies, we use operator data as opposed to data by geographic region (i.e., by country). By so doing, we should be able to isolate the specific effects of operator characteristics that might affect broadband access prices.

However, comparing the broadband tariffs of operators in the same market (rather than between countries) means that we must find different explanatory variables to those employed to date in the literature. For example, previous studies have used the Herfindahl index as a proxy for the level of concentration/competition in a given market (Distaso et al., 2006). In our study, these variables are useless as they estimate the level of competition in a complete geographic market. Instead, therefore, we construct two variables that serve to estimate the impact of each operator on both modes of competition:

INTRA: This variable measures the level of market competition between xDSL platforms, i.e., intra-platform competition. The variable is defined as the total number of alternative xDSL operator subscriptions in relation to the total number of incumbent xDSL subscriptions. Formally:

$\operatorname{INTRA}(i)=\frac{q_{i}}{q_{\text {inc }}}$,

where $q_{i}$ is the number of subscriptions provided by alternative xDSL operator $i$ and $q_{\text {inc }}$ is the number of incumbent $x D S L$ subscriptions. 
INTER: This variable measures the level of market competition between different platforms (xDSL and Cable). The variable is defined as the total number of subscriptions of cable operator $j$ as a share of the whole volume of $\mathrm{XDSL}$ subscriptions in the broadband access market. Formally:

$\operatorname{INTER}(j)=\frac{Y_{j}}{Q}$,

where $Q=\sum_{i}^{n} q_{i}+q_{\text {inc }}$ and $Y j$ is the number of subscriptions provided by cable operator $j$

\subsection{Broadband tariff features}

In order to capture the features of the broadband tariffs, we employ the following variables:

SPEED: Broadband speed (MB) offered at the prevailing broadband tariff.

BUNDLE: A variable that takes the value 0 when the tariff offers only broadband access, 1 when broadband access is bundled with a fixed phone service and 2 when the broadband service is bundled with telephony and television.

BITSTREAM: A variable that takes the value 1 when the service is provided on the basis of reselling or bitstream access to the incumbent's network, and the value 0 when the operator provides broadband services with forms of access on the final rungs of the investment ladder theory (primarily, shared and unbundling local loop). As such, this variable is used to measure the impact of service-based intra-platform competition on price levels.

CAPPED: Dichotomous variable that takes the value 1 when the tariff offers limited data allowances.

\subsection{Network variables}

The variable LINE contains the broadband subscriptions of each telecom operator. Telecom services belong to a network industry and as such are likely to be affected by substantial scale economies. Hence, operators with a large number of subscribers will incur lower costs due to their being able to exploit these economies of scale. 
The following table summarizes the model's explanatory variables, the expected effect of each on the dependent variable, the justification for these expectations, and the empirical literature that supports these expected outcomes:

Table 2. The main variables, hypotheses, arguments and references to the literature

$\begin{array}{llll}\text { Variable Hypothesis } \quad \text { Argument } & \text { Literature }\end{array}$

\begin{tabular}{|c|c|c|c|}
\hline INTRA & $\begin{array}{l}\text { Positive or non- } \\
\text { significant relationship } \\
\text { with broadband } \\
\text { access price }\end{array}$ & $\begin{array}{l}\text { Positive effects of higher intra-platform } \\
\text { competition are offset because this mode } \\
\text { generates, in turn, less inter-platform } \\
\text { competition }\end{array}$ & $\begin{array}{l}\text { Garcia-Murillo \& } \\
\text { Gabel (2003), } \\
\text { Wallsten (2006), } \\
\text { Distaso et al. (2006) } \\
\text { and Bouckaert et al. } \\
\text { (2010). }\end{array}$ \\
\hline INTER & $\begin{array}{l}\text { Negative relationship } \\
\text { with broadband } \\
\text { access price }\end{array}$ & $\begin{array}{l}\text { Rivalry between technological platforms is } \\
\text { one of the most important driving forces } \\
\text { promoting broadband competition. As a result, } \\
\text { a higher inter-platform competition promotes } \\
\text { the broadband penetration rate and impacts } \\
\text { negatively on broadband access prices. }\end{array}$ & $\begin{array}{l}\text { Distaso et al. (2006) } \\
\text { and Bouckaert et al. } \\
\text { (2010) }\end{array}$ \\
\hline SPEED & $\begin{array}{l}\text { Positive relationship } \\
\text { with broadband } \\
\text { access price }\end{array}$ & $\begin{array}{l}\text { Broadband data speed affects consumer } \\
\text { willingness to pay for broadband access } \\
\text { services. }\end{array}$ & $\begin{array}{l}\text { Not considered in the } \\
\text { literature }\end{array}$ \\
\hline BUNDLE & $\begin{array}{l}\text { Positive relationship } \\
\text { with broadband } \\
\text { access price }\end{array}$ & $\begin{array}{l}\text { The greater the number of telecom services } \\
\text { unbundled in the tariff, the higher the prices } \\
\text { the subscriber should pay. }\end{array}$ & $\begin{array}{l}\text { Not considered in the } \\
\text { literature }\end{array}$ \\
\hline BITSTREAM & $\begin{array}{l}\text { Positive relationship } \\
\text { with broadband } \\
\text { access price }\end{array}$ & $\begin{array}{l}\text { Broadband service in geographic areas where } \\
\text { alternative xDSL operators do not invest } \\
\text { sufficiently in facilities is provided primarily } \\
\text { with reseller or bitstream access and, } \\
\text { consequently, prices are higher. }\end{array}$ & $\begin{array}{l}\text { Bouckaert et al. } \\
(2010)\end{array}$ \\
\hline CAPPED & $\begin{array}{l}\text { Negative relationship } \\
\text { with broadband } \\
\text { access price }\end{array}$ & $\begin{array}{l}\text { Limited data allowances negatively affect } \\
\text { consumer willingness to pay for broadband } \\
\text { access services. }\end{array}$ & $\begin{array}{l}\text { Not considered in the } \\
\text { literature }\end{array}$ \\
\hline LINE & $\begin{array}{l}\text { Negative relationship } \\
\text { with broadband } \\
\text { access price }\end{array}$ & $\begin{array}{l}\text { The likely existence of economies of scale } \\
\text { allows operators with large numbers of } \\
\text { subscribers to save costs }\end{array}$ & $\begin{array}{l}\text { Not considered in the } \\
\text { literature }\end{array}$ \\
\hline
\end{tabular}

Although the empirical literature to date analyzes the size of demand - represented by the broadband penetration rate - and we focus on broadband prices, the results of earlier studies remain valid here as the two concepts are inversely proportional.

Note that four of the variables have not, to the best of our knowledge, been analyzed in the existing empirical literature. The evaluation of their impact on broadband access prices is possible here because we analyze the broadband services offered by telecom operators in a single 
geographic market, unlike the majority of previous studies that undertake international comparisons of countries using aggregated data.

Table 3 provides the descriptive statistics of the variables used in the estimation, while Table 4 shows the matrix of bivariate correlations for the variables in Table 2. Note that the LINE and concentration variables (INTRA and INTER) could be highly correlated simply because of the fact that we use the number of subscribers in calculating the concentration variables. A strong correlation would be indicative of a multicollinearity problem and, therefore, the regression coefficients related to the two highly correlated variables would be unreliable.

Nevertheless, the results from the matrix reject this possibility as the correlation between these variables is not considered significant. This can be explained by the fact that the variables capture different effects: on the one hand, LINE captures scale economy effects on broadband prices; on the other, INTRA and INTER seek to capture the two modes of competition in the broadband market.

Table 3. Descriptive statistics

\begin{tabular}{lccccc}
\hline Variable & $\begin{array}{c}\mathrm{N}^{\circ} \text { of } \\
\text { observations }\end{array}$ & Mean & $\begin{array}{c}\text { Standard } \\
\text { Deviation }\end{array}$ & Minimum & Maximum \\
\hline PRICE & 138 & 38.375 & 8.424 & 21.700 & 54.870 \\
\hline INTRA & 138 & 0.071 & 0.076 & 0 & 0.242 \\
\hline INTER & 138 & 0.036 & 0.080 & 0 & 0.259 \\
\hline SPEED & 138 & $5,352.580$ & $6,571.677$ & 256.000 & $20,480.000$ \\
\hline BUNDLE & 138 & 0.739 & 0.457 & 0.000 & 2.000 \\
\hline LINE & 138 & $1,298,841$ & $1,538,084$ & 225 & $5,557,510$ \\
\hline BITSTREAM & 138 & 0.014 & 0.120 & 0 & 1 \\
\hline CAPPED & 138 & 0.123 & 0.330 & 0 & 1 \\
\hline
\end{tabular}


Table 4. Correlation matrix

\begin{tabular}{|l|c|c|c|c|c|c|c|c|c|c|}
\hline & PRICE & INTRA & INTER & SPEED & BUNDLE & LINE & BITSTREAM & $\begin{array}{c}\text { CAPPE } \\
\text { D INDEX }\end{array}$ & YEAR \\
\hline PRICE & 1 & & & & & & & & & \\
\hline INTRA & -0.29 & 1 & & & & & & & & \\
\hline INTER & 0.03 & -0.42 & 1 & & & & & & & \\
\hline SPEED & 0.22 & -0.02 & 0.12 & 1 & & & & & & \\
\hline BUNDLE & 0.16 & 0.23 & -0.02 & 0.35 & 1 & & & & & \\
\hline LINE & 0.11 & -0.06 & 0.18 & 0.08 & -0.07 & 1 & & & & \\
\hline BITSTREAM & 0.01 & 0.15 & -0.05 & -0.04 & -0.19 & 0.01 & 1 & & & \\
\hline CAPPED & -0.39 & -0.20 & -0.10 & -0.18 & -0.31 & 0.17 & -0.04 & 1 & & \\
\hline INDEX & -0.20 & -0.05 & 0.50 & -0.09 & 0.01 & -0.07 & 0.02 & -0.10 & 1 & \\
\hline YEAR & -0.22 & 0.13 & 0.02 & 0.44 & 0.24 & 0.46 & 0.03 & -0.01 & -0.10 & 1 \\
\hline
\end{tabular}

\subsection{Econometric specification and results}

Taking the previous hypotheses into consideration, the equation to be estimated can be expressed in the following linear form:

$$
\begin{aligned}
\operatorname{LogPRICE}_{i, t}= & \text { const }+\beta_{1} \text { INTRA }_{i, t-1}+\beta_{2} \operatorname{INTER}_{i, t-1}+\beta_{3} \operatorname{LogSPEED}_{i, t} \\
& +\beta_{4} \text { BUNDLED }_{i, t}+\beta_{5} \operatorname{LogLINE}_{i, t-1}+\beta_{6} \text { BITSTREAM }_{i, t}+\beta_{7} \text { CAPPED }_{i, t}
\end{aligned}
$$

The monthly rental price of broadband access provided by operator $i$ at moment $t$ is a function of (a) the level of competition within XDSL platform (INTRA) at moment $t-1$, (b) the level of competition between different technology platforms providing broadband access (INTER) at moment $t-1$, (c) the broadband speed offered in the tariff (SPEED) at moment $t$, (d) the number of telecom services available as a bundle in the tariff (BUNDLE) at moment $t$, (e) the number of subscriptions held by operator $i$ (LINE) at moment $t-1$, (f) the fact of reseller or bistream modality being used by operator $i$ to provide broadband services (BITSTREAM) at moment $t$, and $(\mathrm{g})$ the limited data allowances included in the tariff (CAPPED) at moment $t$. 
As for the dependent variable (PRICE), the value of the price variable at moment $t$ is unlikely to be independent of the value of that variable at moment $t-1$. For this reason a serial autocorrelation problem is likely to exist, that is, there might well be a correlation between the error terms at different points in time. In this regard, the Wooldridge test results confirm the existence of serial autocorrelation. Thus, we ran the regressions accounting for the presence of autoregressive residuals.

The price equation includes several one-period lagged explanatory variables $(t-1)$ given that their full effect takes time to make an impact on the dependent variable. Intra-platform competition (INTRA), inter-platform competition (INTER) and the size of the company (LINE) do not affect broadband prices during the same period, but rather have an impact on the operators' future pricing strategies.

Our empirical analysis also takes into account differences between the six operators, which is critical for accounting effectively for their specific characteristics. Operators are likely to differ in terms of their productive efficiency, facilities, and the like. In general, two types of model are available for capturing cross-sectional heterogeneity in the context of a panel data model: fixed effects and random effects models. In both specifications, specific effects are estimated for each operator, but the models differ in terms of whether the operator effects are modeled as predetermined or as random form. In practice, this difference can be critical as the results from fixed effects and random effects models may diverge significantly.

Statistically, fixed effects can always be used with panel data as they invariably provide consistent results, but they may not be the most efficient model to run. The reason for their inefficiency is that fixed effects estimations only capture the within variation. By contrast, random effects provide a more efficient estimator because they take into account both within and between variations. Yet, the random effects estimation might not be consistent because these effects might be correlated with the explanatory variables. The Hausman test can be used to choose the most appropriate model in our context.

In addition, and as explained above, a final refinement has been made to the model to correct for serial correlation. Thus, the first and second columns in Table 6 display the estimates for the fixed effects and random effects specifications with the inclusion of a first-order autoregressive random disturbance term. Finally, for the sake of completeness, we estimate the ordinary least squares (OLS) pooled model with the serial correlation removed using the Prais-Winsten method. 
Table 6. Results for broadband prices in the Spanish market (Dependent variable: logPRICE)

\begin{tabular}{|c|c|c|c|}
\hline & Fixed Effects AR(1) & Random Effects AR(1) & Pooled OLS AR(1) \\
\hline INTRA & $\begin{array}{c}-2.093876^{* * *} \\
(.5892367)\end{array}$ & $\begin{array}{c}-.6047259 * \\
(.374151)\end{array}$ & $\begin{array}{c}-.7925918 \text { ** } \\
(.418387)\end{array}$ \\
\hline INTER & $\begin{array}{c}1.748077 \\
(1.805935)\end{array}$ & $\begin{array}{l}.0930224 \\
(.4284781)\end{array}$ & $\begin{array}{l}-.2781357 \\
(.380742)\end{array}$ \\
\hline logSPEED & $\begin{array}{l}.0339936 \text { ** } \\
(.0164309)\end{array}$ & $\begin{array}{l}.0223975 * \\
(.0132035)\end{array}$ & $\begin{array}{l}.0302341^{* *} \\
(.0156207)\end{array}$ \\
\hline BUNDLE & $\begin{array}{l}.0217309 \\
(.0284938)\end{array}$ & $\begin{array}{l}.0303285 \\
(.0247976)\end{array}$ & $\begin{array}{l}.0324847 \\
(.0229636)\end{array}$ \\
\hline logLINE & $\begin{array}{l}.2882073^{* * *} \\
(.0386816)\end{array}$ & $\begin{array}{l}-.0168363 \\
(.0113629)\end{array}$ & $\begin{array}{l}.0040782 \\
(.01868)\end{array}$ \\
\hline BITSTREAM & $\begin{array}{l}.1945929 * * * \\
(.0749071)\end{array}$ & $\begin{array}{l}.1544576 \text { ** } \\
(.0726255)\end{array}$ & $\begin{array}{l}.1278966^{*} \\
(.0802769)\end{array}$ \\
\hline CAPPED & $\begin{array}{l}-.090846 * \\
(.0537335)\end{array}$ & $\begin{array}{l}-.202256 \text { *** } \\
(.0446619)\end{array}$ & $\begin{array}{c}-.2284793 \text { *** } \\
(.0493321)\end{array}$ \\
\hline Const & $\begin{array}{c}-.5469296 \text { ** } \\
(.2807027)\end{array}$ & $\begin{array}{c}3.704808^{* * *} \\
(.1413816)\end{array}$ & $\begin{array}{c}3.405026 * * * \\
(.2418176)\end{array}$ \\
\hline $\mathrm{N}$ & 126 & 126 & 138 \\
\hline $\mathrm{R}^{2}$ & 0.4591 & 0.2317 & 0.9568 \\
\hline $\begin{array}{l}\text { Hausman Tes } \\
\text { FE) }\end{array}$ & (RE vs & $79.42 * * *$ & \\
\hline Baltagi-Wu Te & 1.3975 & 1.3975 & \\
\hline
\end{tabular}

Under the null hypothesis of zero correlation between the error term and the regressors, the results of the Hausman test indicate that the null hypothesis of orthogonality is rejected. As a result, the panel data model with fixed effects is preferred to that with random effects. Therefore, we focus the rest of our discussion on the estimates obtained from the panel data model with fixed effects, but note that all the estimated models produced fairly similar results. The estimation based on fixed effects (FE) gave an $R^{2}$ of 0.4591 , which confirms that the proposed model provides a satisfactory fit of the explanatory power. The result of the Baltagi-Wu test supports the adjustments carried out in accordance with the Wooldridge test results and also confirms that the problem of autocorrelation has been successfully corrected.

Our results for the two variables measuring the degree of market competition show that each mode of competition has a different impact on broadband access prices. Hence, while competition between xDSL platforms (INTRA) has a negative and significant effect on the price level in three of the models estimated, competition between different technological platforms (INTER) is not 
significant in any case. In other words, intra-platform competition is the key variable to understand the evolution in broadband prices in the Spanish market.

As for the variables used to define the characteristics of the broadband tariffs, all are found to have a significant impact on the dependent variable with the exception of the dichotomous variable used to specify how many services are bundled in the tariff (BUNDLE). Hence, the BUNDLE variable is insignificant because operators tend to include fixed phone services in broadband tariffs without any additional price increase.

The broadband speed variable (SPEED) has a significant and positive effect on broadband prices. Thus, the faster the broadband speed subscribers contract, the more expensive are the tariffs they pay.

The dummy variable which reveals whether the service is provided by reseller or bitstream access (BITSTREAM) is significant and positive, i.e. the offers provided by this modality of access are more highly priced because the tariffs are offered in places where alternative operators have yet to invest sufficiently in network facilities. This result suggests that service-based intra-platform competition would not help to reduce broadband prices.

The limited data allowances variable (CAPPED) is significant and negative as such tariffs target subscribers with lower data usage. Consequently, consumers that accept this limitation benefit from discounted prices.

The size of each operator in terms of their respective number of subscribers (LINE) is shown to be significant and positive. This result therefore rejects the hypothesis that larger operators set lower prices thanks to the existence of scale economies.

The estimated results reported here differ from those reported previously. First, our results suggest that the degree of competition within xDSL platform (INTRA) is critical in explaining the price level of broadband access services in the Spanish market. By contrast, previous studies, including Distaso et al. (2006) and Bouckaert et al. (2010), report that this variable has an insignificant or even negative impact on the market. Second, the aforementioned studies identify inter-platform competition as the driving force in the promotion of broadband adoption. This result runs contrary to the obtained here, given that the variable measuring this form of competition (INTER) is not significant.

Given these results, we infer that broadband prices in countries such as Spain, characterized as they are by a lower rate of development of their broadband markets, may respond differently to the various modes of competition. Indeed, we have observed differences between countries with 
regard to the diffusion of their cable platforms: even though all cable operators have had to invest in order to provide a broadband service, the initial investment required to start this service was not similar in all countries. The reason lies in the fact that, before expanding their broadband services, several countries built a cable network dedicated to broadcasting audiovisual content, whereas in other countries the presence of cable networks was only residual as audiovisual content was broadcast by alternative networks (for example, in the case of Spain, this service was provided by radio waves). Thus, the supply of cable broadband services in this latter group of countries meant their having to start from scratch the construction of a new network. Consequently, the investment required in this group of countries was much higher than that in countries where a cable network with national coverage already existed.

This high level of initial investment may have weakened the competitiveness of the new cable operators with respect to those that had been supplying broadcasting services for years in other countries. The competitive weakness of the cable networks in these countries would seem to have ensured that it was the intra-platform competition that became the real driving force in the diffusion of broadband services.

In short, the theoretically positive effects of the emergence of a new broadband platform appear not solely to be determined by its mere creation, but are also influenced by other circumstances that might even undermine the potential benefits.

\section{Conclusions}

This paper has analyzed the main variables that account for the evolution of broadband technology and a set of related factors in the Spanish market. The literature tends to identify interplatform competition, i.e., the competition that exists between platforms based on different technologies, as one of the main factors driving the international expansion of broadband services. By contrast, intra-platform competition, i.e., the competition generated from regulating access by alternative operators to the incumbent operator's platform, has had a much weaker impact on the development of the broadband market, with some studies concluding that it can even have a detrimental impact on its expansion.

Our analysis, however, points to the fact that these earlier findings are not necessarily valid for all countries, an example being the Spanish market. As outlined in this paper, the diffusion of broadband access in Spain shows a delay with respect to the average rates achieved in other European countries in terms both of penetration rates and of prices. Our results for the Spanish 
case are diametrically opposed to those reported in most studies in the literature; to the effect that the intra-platform competition has been the main driving force for the expansion of broadband access in Spain, whereas the inter-platform competition appears to have had no impact on its development.

This result suggests that the Spanish market has benefited from potentially positive effects in line with predictions made in the framework of the investment ladder theory. In other words, the regulation of access to the incumbent's platform for alternative operators has emerged as a key variable in promoting broadband adoption. By contrast, the positive effects attributed to the competition between different technologies have not been recorded in the case of the Spanish market. It is our belief that external variables that could affect the potential platform and, therefore, inter-platform competition, must be taken into account. The presence in some countries of cable TV platforms before the emergence of broadband services would seem to be a basic element in determining the competitiveness of this technological platform.

In short, policymakers seeking to place their countries at the forefront of telecommunication technology need to encourage broadband uptake. This goal, however, can only be achieved by increasing the competitive pressure on the pricing of such services. In order to fulfill these objectives, the promotion of tools that can ensure that the market will benefit from inter-platform competition seems essential. Failure to do so might mean that external variables related to the specific characteristics of the national markets can neutralize these potentially positive effects. Today, this question is acquiring even greater importance, at a time when new technology platforms based on optic fiber are set to generate major economic benefits. 


\section{References}

Aron, D.J. and Burnstein, D.E. (2003) Broadband adoption in the United States: an empirical analysis. Paper presented at the 31th Research Conference on Communication, Information and Internet Policy. Arlington, VA, USA

Andres L., Cuberes D., Diouf M. (2010) The diffusion of the Internet: A cross-country analysis. Telecommunications Policy, Vol. 34, n4, pp. 323-340

Beilock, R. and Dimitrova, D.V. (2003) An exploratory model of inter-country Internet diffusion. Telecommunications Policy, 27, pp. 237-252.

Bouckaert, J., van Dijk, Th. and Verboeven, F. (2010) Access regulation, competition, and broadband penetration: an international study. Telecommunications Policy, 34, pp.661-671

Bourreau, M. and Dogan, P. (2006) Build-or-Buy. Strategies in the Local Loop. American Economic Review, 96, pp.72-76.

Cambini, C. and Jiang, Y. (2009) Broadband Investment and Regulation. A Literature Review. Telecommunications Policy, 33, pp.559-574.

Cave, M., Majumdar, S., Rood H., Valletti, T. and Vogelsang, I. (2001) The Relationship between Access Pricing Regulation and Infrastructure Competition. Report to OPTA and DG Telecommunications and Post by Brunel University

Cave, M. and Vogelsang, I. (2003) How Access pricing and entry interact. Telecommunications Policy, 27, pp. 717-727

Cave, M. (2007) The regulation of access in telecommunications: a European perspective. Warwick Business School, University of Warwick

CoCOM (2011) Broadband access in the EU: situation at 1 July 2011. Working Document

CMT (2010) Comparativa internacional de ofertas comerciales de banda ancha en la Unión Europea, Diciembre

Crandall, R.W. and Jackson, C.L. (2001) The $\$ 500$ Billion Opportunity: The Potential Economic Benefit of Widespread Diffusion of Broadband Internet Access. Criterion Economics

Crandall, R., Ingraham, A., and Singer, H. (2004) Do unbundling policies discourage CLEC facilities-based investment? Topics in Economic Analysis and Policy 4(1), pp.1-23.

Distaso, W., Lupi, P. and Manenti, F. M. (2006) Platform competition and broadband uptake: Theory and empirical evidence from the European Union. Information Economics and Policy, 18, pp.87-106

Ferguson, C. (2002) The United States Broadband Problem: Analysis and Recommendations, mimeo, Brookings Institution. Washington, DC

Ford, G.S. and Koutsky, T.M. (2005) Broadband and economic development: a municipal case study from Florida. Applied Economic Studies 1. April, pp. 1-17 
Garcia-Murillo, M. and Gabel, D. (2003) International Broadband deployment: The Impact of Unbundling. Paper presented at the 31st Research Conference on Communication, Information and Internet Policy. Arlington, VA, USA

Hausman, J.A., Sidak, J.G. and Singer, H.J. (2001) Cable modems and DSL: broadband Internet access for residential customers. American Economic Review, 91, 302-307

Hori, K. and Mizuno, K. (2009) Competition scheme and investment with stochastically growing demand. International Journal of Industrial Organization, 24(4), pp. 705-808.

ITU (2011) World Telecommunication/ICT Indicators Database (15th Edition)

Katz, R.L. and Suter, S. (2009) Estimating the economic impact of the broadband stimulus plan.

Columbia Institute for Tele-Information Working Paper

Kingsley, L (2005) iProvo Utah: 100 Mbps for All. Broadband Properties, January, pp. 14-18

Koutroumpis, A. (2009) The economic impact of broadband on growth: A simultaneous approach.

Telecommunications Policy, pp. 471-485

Lehr, W., Osorio, C., Gillett, S. and Sirbu, M. (2006) Measuring broadband economic impact.

Paper presented at the 33rd Research Conference on Communications, Information and Internet Policy. September 23-25, Arlington, Va

Menzie D. Chinn and Robert W. Fairlie (2007) The determinants of the global digital divide: a cross-country analysis of computer and internet penetration. Oxford Economic Papers, Oxford University Press, vol. 59(1), pp. 16-44, January

MICUS Management Consulting GmbH (2010) The Impact of Broadband on Growth and Productivity. A study on behalf of the European Commission (DG Information Society and Media)

OECD (2011) OECD Communications Outlook

Qiang, C. Z., and Rossotto, C. M. (2009) Economic Impacts of Broadband. In Information and Communications for Development 2009: Extending Reach and Increasing Impact, 35-50. Washington, DC: World Bank.

Ross, S.S. (2006) A mayor's guide to FTTH: P2P, GePON, PON, GPON - what does it all mean? Broadband properties, May, pp. 32-37

Van Dijk Management Consultants (2010) Broadband Internet Access Cost (BIAC). European Commission, Information Society and Media Directorate-General, Brussels.

Wallsten, S. (2006) Broadband and Unbundling Regulations in OECD Countries. AEI-Brookings Joint Center for Regulatory Studies. Working Paper 06-16, Washington, D.C.

Withman, B. (2005) FTTH expands fast around the world. Broadband Properties, September, pp. $42-45$

Wooldridge, J., M. (2002) Econometric Analysis of Cross Section and Panel Data, The MIT Press, Cambridge, M.A. 
Llista Document de Treball

\section{List Working Paper}

WP 2013/03 "Determinants of Broadband Access: Is Platform Competition always the Key Variable to Success?" Fageda, X.; Rubio, R. and Termes, M.

WP 2013/02 "Beyond Value-at-Risk: GlueVaR Distortion Risk Measures" Belles-Sampera, J.; Guillén, M. and Santolino, M.

WP 2013/01 "How systemic is Spain for Europe?" Claeys, P. and Vašícek, B.

WP 2012/24 "Changes in Wage Structure in Mexico Going Beyond the Mean: An Analysis of Differences in Distribution, 1987-2008" Tello, C.; Ramos, R, and Artís, M.

WP 2012/23 "Decomposing the Rural-Urban Differential in Student Achievement in Colombia Using PISA Microdata" Ramos, R.; Duque, J.C. and Nieto, S.

WP 2012/22 "Recovery Risk and Labor Costs in Public-Private-Partnerships: Contractual Choice in the U.S. Water industry" Albalate, D, Bel, G. and Geddes, R.

WP 2012/21 "Beyond pure public and pure private management models: Mixed firms in the European Airport Industry" Albalate, D.; Bel, G. and Fageda, X.

WP 2012/20 "The determinants of contractual choice for private involvement in infrastructure projects in the United States" Albalate, D, Bel, G. and Geddes, R.

WP 2012/19 "Measuring Sovereign Bond Spillover in Europe and the Impact of Rating News" Claeys, P. and Vašíček, B.

WP 2012/18 "Entry Regulation Asymmetries and Gasoline Competition in a Mixed Motorway Network" Albalate, D. and Perdiguero, J.

WP 2012/17 "Regulation of Port Charges in Spain: Global versus Local Competition" Fageda, X. and Gonzalez-Aregall, M.

WP 2012/16 "Pass-through in dollarized countries: should Ecuador abandon the U.S. Dollar?" Marí del Cristo, M.L. and Gómez-Puig, M.

WP 2012/15 "A Note on the Relationship Between the Cyclicality of Markups and Fiscal Policy" Claeys, P. and Costa, L.F.

WP 2012/14 "Do intra- and inter-industry spillovers matter? CDM model estimates for Spain" Goya, E.; Vayá, E and Suriñach, J.

WP 2012/13 "What Drives the Choice of Partners in R\&D Cooperation? Heterogeneity across Sectors" Badillo, E. and Moreno, R.

WP 2012/12 "Corruption and local politics: does it pay to be a crook?" Jiménez, J.L. and García, C.

WP 2012/11 "Not always sunny in paradise: prices and brand diversity in touristic areas supermarkets" Campos, J.; Jiménez, J.L. and Suárez-Alemán, A.

WP 2012/10 "The institutional, economic and social determinants of local government transparency" Albalate, D.

WP 2012/09 "The business excellence attraction composite index (BEACl). Design and apllication to the municipalities of the Barcelona province" Murillo, J.; Romaní, J.; Suriñach, J.

WP 2012/08 "Policy options for the promotion of electric vehicles: a review" Perdiguero, J. and Jiménez, J.L. 
WP 2012/07 "Price differences between domestic and international air markets: an empirical application to routes from Gran Canaria" Fageda, X.; Jiménez, J.L. and Díaz Santamaría, C.

WP 2012/06 "Building a "quality in work" index in Spain" López-Tamayo, J.; Royuela, V. and Suriñach, J.

WP 2012/05 "Mergers and difference-in-difference estimator: why firms do not increase prices?" Jiménez, J.L. and Perdiguero, J.

WP 2012/04 "What attracts knowledge workers? The role of space, social connections, institutions, jobs and amenities" Miguélez, E. and Moreno, R.

WP 2012/03 "What Drives the Urban Wage Premium? Evidence along the Wage Distribution" Matano, A. and Naticchioni, $P$.

WP 2012/02 "Location Patterns of Creative Capital and Regional Disparities in Spain" Kerimoglu, E. and Karahasan, B.C.

WP 2012/01 "The connection between distortion risk measures and ordered weighted averaging operators" Belles-Sampera, J.; Merigó, J.M.; Guillén, M. and Santolino, M.

WP 2011/26 "Productivity and innovation spillovers: Micro evidence from Spain" Goya, E.; Vayá, E. and Suriñach, J.

WP 2011/25 "The regional distribution of unemployment. What do micro-data tell us?" López-Bazo, E. and Motellón, E.

WP 2011/24 "Vertical relations and local competition: an empirical approach" Perdiguero, J.

WP 2011/23 "Air services on thin routes: Regional versus low-cost airlines" Fageda, X. and Flores-Fillol, R.

WP 2011/22 "Measuring early childhood health: a composite index comparing Colombian departments" Osorio, A.M.; Bolancé, C. and Alcañiz, M.

WP 2011/21 "A relational approach to the geography of innovation: a typology of regions" Moreno, $\mathrm{R}$. and Miguélez, E.

WP 2011/20 “Does Rigidity of Prices Hide Collusion?” Jiménez, J.L and Perdiguero, J.

WP 2011/19 "Factors affecting hospital admission and recovery stay duration of in-patient motor victims in Spain" Santolino, M.; Bolancé, C. and Alcañiz, M.

WP 2011/18 "Why do municipalities cooperate to provide local public services? An empirical analysis" Bel, G.; Fageda, X. and Mur, M.

WP 2011/17 "The "farthest" need the best. Human capital composition and development-specific economic growth" Manca, F.

WP 2011/16 "Causality and contagion in peripheral EMU public debt markets: a dynamic approach" Gómez-Puig, M. and Sosvilla-Rivero, S.

WP 2011/15 "The influence of decision-maker effort and case complexity on appealed rulings subject to multi-categorical selection" Santolino, M. and Söderberg, M.

WP 2011/14 "Agglomeration, Inequality and Economic Growth" Castells, D. and Royuela, V.

WP 2011/13 "A correlation sensitivity analysis of non-life underwriting risk in solvency capital requirement estimation" Bermúdez, L.; Ferri, A. and Guillén, M.

WP 2011/12 "Assessing agglomeration economies in a spatial framework with endogenous regressors" Artis, M.J.; Miguélez, E. and Moreno, R.

WP 2011/11 "Privatization, cooperation and costs of solid waste services in small towns" Bel, G; Fageda, $\mathrm{X}$. and Mur, M. 
WP 2011/10 "Privatization and PPPS in transportation infrastructure: Network effects of increasing user fees" Albalate, D. and Bel, G.

WP 2011/09 "Debating as a classroom tool for adapting learning outcomes to the European higher education area" Jiménez, J.L.; Perdiguero, J. and Suárez, A.

WP 2011/08 "Influence of the claimant's behavioural features on motor compensation outcomes" Ayuso, M; Bermúdez L. and Santolino, M.

WP 2011/07 "Geography of talent and regional differences in Spain" Karahasan, B.C. and Kerimoglu E.

WP 2011/06 "How Important to a City Are Tourists and Daytrippers? The Economic Impact of Tourism on The City of Barcelona" Murillo, J; Vayá, E; Romaní, J. and Suriñach, J.

WP 2011/05 "Singling out individual inventors from patent data" Miguélez,E. and Gómez-Miguélez, I.

WP 2011/04 “¿La sobreeducación de los padres afecta al rendimiento académico de sus hijos?" Nieto, S; Ramos, R.

WP 2011/03 “The Transatlantic Productivity Gap: Is R\&D the Main Culprit?" Ortega-Argilés, R.; Piva, M.; and Vivarelli, M.

WP 2011/02 "The Spatial Distribution of Human Capital: Can It Really Be Explained by Regional Differences in Market Access?" Karahasan, B.C. and López-Bazo, E

WP 2011/01 "I If you want me to stay, pay" . Claeys, P and Martire, F

WP 2010/16 "Infrastructure and nation building: The regulation and financing of network transportation infrastructures in Spain (1720-2010)"Bel,G

WP 2010/15 "Fiscal policy and economic stability: does PIGS stand for Procyclicality In Government Spending?" Maravalle, A ; Claeys, P.

WP 2010/14 "Economic and social convergence in Colombia" Royuela, V; Adolfo García, G.

WP 2010/13 "Symmetric or asymmetric gasoline prices? A meta-analysis approach" Perdiguero, J.

WP 2010/12 “Ownership, Incentives and Hospitals” Fageda,X and Fiz, E.

WP 2010/11 "Prediction of the economic cost of individual long-term care in the Spanish population" Bolancé, C; Alemany, R ; and Guillén M

WP 2010/10 "On the Dynamics of Exports and FDI: The Spanish Internationalization Process" MartínezMartín J.

WP 2010/09 “Urban transport governance reform in Barcelona” Albalate, D ; Bel, G and Calzada, J.

WP 2010/08 "Cómo (no) adaptar una asignatura al EEES: Lecciones desde la experiencia comparada en España" Florido C. ; Jiménez JL. and Perdiguero J.

WP 2010/07 "Price rivalry in airline markets: A study of a successful strategy of a network carrier against a low-cost carrier" Fageda, X ; Jiménez J.L. ; Perdiguero, J.

WP 2010/06 "La reforma de la contratación en el mercado de trabajo: entre la flexibilidad y la seguridad" Royuela V. and Manuel Sanchis M.

WP 2010/05 "Discrete distributions when modeling the disability severity score of motor victims" Boucher, J and Santolino, M

WP 2010/04 "Does privatization spur regulation? Evidence from the regulatory reform of European airports . Bel, G. and Fageda, X."

WP 2010/03 "High-Speed Rail: Lessons for Policy Makers from Experiences Abroad". Albalate, D ; and Bel, G."

WP 2010/02 "Speed limit laws in America: Economics, politics and geography". Albalate, D ; and Bel, G." 
WP 2010/01 "Research Networks and Inventors' Mobility as Drivers of Innovation: Evidence from Europe" Miguélez, E. ; Moreno, R. "

WP 2009/26 "Social Preferences and Transport Policy: The case of US speed limits" Albalate, D.

WP 2009/25 "Human Capital Spillovers Productivity and Regional Convergence in Spain", Ramos, R ; Artis, M.; Suriñach, J.

WP 2009/24 “Human Capital and Regional Wage Gaps”,López-Bazo,E. Motellón E.

WP 2009/23 "Is Private Production of Public Services Cheaper than Public Production? A metaregression analysis of solid waste and water services" Bel, G.; Fageda, X.; Warner. M.E.

WP 2009/22 "Institutional Determinants of Military Spending” Bel, G., Elias-Moreno, F.

WP 2009/21 "Fiscal Regime Shifts in Portugal” Afonso, A., Claeys, P., Sousa, R.M.

WP 2009/20 "Health care utilization among immigrants and native-born populations in 11 European countries. Results from the Survey of Health, Ageing and Retirement in Europe" Solé-Auró, A., Guillén, M., Crimmins, E.M.

WP 2009/19 "La efectividad de las políticas activas de mercado de trabajo para luchar contra el paro. La experiencia de Cataluña" Ramos, R., Suriñach, J., Artís, M.

WP 2009/18 "Is the Wage Curve Formal or Informal? Evidence for Colombia" Ramos, R., Duque, J.C., Suriñach, J.

WP 2009/17 "General Equilibrium Long-Run Determinants for Spanish FDI: A Spatial Panel Data Approach" Martínez-Martín, J.

WP 2009/16 "Scientists on the move: tracing scientists' mobility and its spatial distribution" Miguélez, E.; Moreno, R.; Suriñach, J.

WP 2009/15 "The First Privatization Policy in a Democracy: Selling State-Owned Enterprises in 19481950 Puerto Rico" Bel, G.

WP 2009/14 "Appropriate IPRs, Human Capital Composition and Economic Growth” Manca, F.

WP 2009/13 "Human Capital Composition and Economic Growth at a Regional Level" Manca, F.

WP 2009/12 "Technology Catching-up and the Role of Institutions" Manca, F.

WP 2009/11 "A missing spatial link in institutional quality" Claeys, P.; Manca, F.

WP 2009/10 "Tourism and Exports as a means of Growth" Cortés-Jiménez, I.; Pulina, M.; Riera i Prunera, C.; Artís, M.

WP 2009/09 "Evidence on the role of ownership structure on firms' innovative performance" OrtegaArgilés, R.; Moreno, R.

WP 2009/08 “¿Por qué se privatizan servicios en los municipios (pequeños)? Evidencia empírica sobre residuos sólidos y agua" Bel, G.; Fageda, X.; Mur, M.

WP 2009/07 "Empirical analysis of solid management waste costs: Some evidence from Galicia, Spain" Bel, G.; Fageda, X.

WP 2009/06 "Intercontinental fligths from European Airports: Towards hub concentration or not?" Bel, G.; Fageda, $\mathrm{X}$.

WP 2009/05 "Factors explaining urban transport systems in large European cities: A cross-sectional approach" Albalate, D.; Bel, G. 
WP 2009/04 "Regional economic growth and human capital: the role of overeducation" Ramos, R.; Suriñach, J.; Artís, M.

WP 2009/03 "Regional heterogeneity in wage distributions. Evidence from Spain" Motellón, E.; LópezBazo, E.; El-Attar, M.

WP 2009/02 "Modelling the disability severity score in motor insurance claims: an application to the Spanish case" Santolino, M.; Boucher, J.P.

WP 2009/01 "Quality in work and aggregate productivity" Royuela, V.; Suriñach, J.

WP 2008/16 "Intermunicipal cooperation and privatization of solid waste services among small municipalities in Spain" Bel, G.; Mur, M.

WP 2008/15 "Similar problems, different solutions: Comparing refuse collection in the Netherlands and Spain" Bel, G.; Dijkgraaf, E.; Fageda, X.; Gradus, R.

WP 2008/14 "Determinants of the decision to appeal against motor bodily injury settlements awarded by Spanish trial courts" Santolino, M

WP 2008/13 "Does social capital reinforce technological inputs in the creation of knowledge? Evidence from the Spanish regions" Miguélez, E.; Moreno, R.; Artís, M.

WP 2008/12 “Testing the FTPL across government tiers” Claeys, P.; Ramos, R.; Suriñach, J.

WP 2008/11 "Internet Banking in Europe: a comparative analysis" Arnaboldi, F.; Claeys, P.

WP 2008/10 "Fiscal policy and interest rates: the role of financial and economic integration" Claeys, P.; Moreno, R.; Suriñach, J.

WP 2008/09 "Health of Immigrants in European countries" Solé-Auró, A.; M.Crimmins, E.

WP 2008/08 "The Role of Firm Size in Training Provision Decisions: evidence from Spain" Castany, L.

WP 2008/07 "Forecasting the maximum compensation offer in the automobile BI claims negotiation process" Ayuso, M.; Santolino, M.

WP 2008/06 "Prediction of individual automobile RBNS claim reserves in the context of Solvency II" Ayuso, M.; Santolino, M.

WP 2008/05 "Panel Data Stochastic Convergence Analysis of the Mexican Regions" Carrion-i-Silvestre, J.L.; German-Soto, V.

WP 2008/04 "Local privatization, intermunicipal cooperation, transaction costs and political interests: Evidence from Spain" Bel, G.; Fageda, X.

WP 2008/03 "Choosing hybrid organizations for local services delivery: An empirical analysis of partial privatization" Bel, G.; Fageda, X.

WP 2008/02 "Motorways, tolls and road safety. Evidence from European Panel Data" Albalate, D.; Bel, G.

WP 2008/01 "Shaping urban traffic patterns through congestion charging: What factors drive success or failure?" Albalate, D.; Bel, G.

WP 2007/19 "La distribución regional de la temporalidad en España. Análisis de sus determinantes" Motellón, E.

WP 2007/18 "Regional returns to physical capital: are they conditioned by educational attainment?" López-Bazo, E.; Moreno, R.

WP 2007/17 "Does human capital stimulate investment in physical capital? evidence from a cost system framework" López-Bazo, E.; Moreno, R. 
WP 2007/16 "Do innovation and human capital explain the productivity gap between small and large firms?" Castany, L.; López-Bazo, E.; Moreno, R.

WP 2007/15 "Estimating the effects of fiscal policy under the budget constraint" Claeys, P.

WP 2007/14 "Fiscal sustainability across government tiers: an assessment of soft budget constraints" Claeys, P.; Ramos, R.; Suriñach, J.

WP 2007/13 "The institutional vs. the academic definition of the quality of work life. What is the focus of the European Commission?" Royuela, V.; López-Tamayo, J.; Suriñach, J.

WP 2007/12 "Cambios en la distribución salarial en españa, 1995-2002. Efectos a través del tipo de contrato" Motellón, E.; López-Bazo, E.; El-Attar, M.

WP 2007/11 "EU-15 sovereign governments' cost of borrowing after seven years of monetary union" Gómez-Puig, M..

WP 2007/10 "Another Look at the Null of Stationary Real Exchange Rates: Panel Data with Structural Breaks and Cross-section Dependence" Syed A. Basher; Carrion-i-Silvestre, J.L.

WP 2007/09 "Multicointegration, polynomial cointegration and I(2) cointegration with structural breaks. An application to the sustainability of the US external deficit" Berenguer-Rico, V.; Carrion-iSilvestre, J.L.

WP 2007/08 "Has concentration evolved similarly in manufacturing and services? A sensitivity analysis" Ruiz-Valenzuela, J.; Moreno-Serrano, R.; Vaya-Valcarce, E.

WP 2007/07 "Defining housing market areas using commuting and migration algorithms. Catalonia (Spain) as an applied case study" Royuela, C.; Vargas, M.

WP 2007/06 "Regulating Concessions of Toll Motorways, An Empirical Study on Fixed vs. Variable Term Contracts" Albalate, D.; Bel, G.

WP 2007/05 "Decomposing differences in total factor productivity across firm size" Castany, L.; LopezBazo, E.; Moreno, R.

WP 2007/04 "Privatization and Regulation of Toll Motorways in Europe" Albalate, D.; Bel, G.; Fageda, X.

WP 2007/03 "Is the influence of quality of life on urban growth non-stationary in space? A case study of Barcelona" Royuela, V.; Moreno, R.; Vayá, E.

WP 2007/02 "Sustainability of EU fiscal policies. A panel test" Claeys, P.

WP 2007/01 "Research networks and scientific production in Economics: The recent spanish experience" Duque, J.C.; Ramos, R.; Royuela, V.

WP 2006/10 "Term structure of interest rate. European financial integration" Fontanals-Albiol, H.; RuizDotras, E.; Bolancé-Losilla, C.

WP 2006/09 "Patrones de publicación internacional (ssci) de los autores afiliados a universidades españolas, en el ámbito económico-empresarial (1994-2004)" Suriñach, J.; Duque, J.C.; Royuela, V.

WP 2006/08 "Supervised regionalization methods: A survey" Duque, J.C.; Ramos, R.; Suriñach, J.

WP 2006/07 "Against the mainstream: nazi privatization in 1930s germany" Bel, G.

WP 2006/06 "Economía Urbana y Calidad de Vida. Una revisión del estado del conocimiento en España" Royuela, V.; Lambiri, D.; Biagi, B.

WP 2006/05 "Calculation of the variance in surveys of the economic climate" Alcañiz, M.; Costa, A.; Guillén, M.; Luna, C.; Rovira, C.

WP 2006/04 "Time-varying effects when analysing customer lifetime duration: application to the insurance market” Guillen, M.; Nielsen, J.P.; Scheike, T.; Perez-Marin, A.M. 
WP 2006/03 "Lowering blood alcohol content levels to save lives the european experience" Albalate, D.

WP 2006/02 "An analysis of the determinants in economics and business publications by spanish universities between 1994 and 2004" Ramos, R.; Royuela, V.; Suriñach, J.

WP 2006/01 "Job losses, outsourcing and relocation: empirical evidence using microdata" Artís, M.; Ramos, R.; Suriñach, J. 


\section{$\mathbb{\Phi}_{\mathbb{1}}|\mathrm{R}| \mathrm{E}|\mathrm{A}|$}

Institut de Recerca en Economia Aplicada Regional i Pública

Research Institute of Applied Economics

\section{Universitat de Barcelona}

Av. Diagonal, 690 • 08034 Barcelona

WEBSITE: www.ub.edu/irea/•CONTACT: irea@ub.edu 